\title{
VÝVOJ VYUŽITÍ KRAJINY KYJOVSKÉ PAHORKATINY, DISKUZE K CENNÝM HISTORICKÝM STRUKTURÁM KRAJINY, JEJICH OCHRANĚ, MANAGEMENTU A POTENCIÁLNÍ OBNOVĚ
}

\author{
Marek Havlíček, Hana Skokanová, Bořivoj Šarapatka, Patrik Netopil, \\ Renata Pavelková
}

\begin{abstract}
The article focuses on the identification of valuable landscape structures in a typical Central European hilly landscape (Kyjovská pahorkatina hilly land) with traces of traditional land use management, and on the assessment of their importance from the perspective of soil protection, nature conservation and landscape character. We used old topographic maps, cadastral maps and aerial photos, covering period 1830s-2010s. Arable land dominated throughout the whole research period. Area of permanent grassland dropped from $17 \%$ to $1 \%$ (in 1991), reflecting the most significant changes in the researched region disappearance of grassland along water courses, pastures as well as a mosaic of small agricultural holdings, representing traditional agricultural landscapes with small vineyards, orchards and arable fields. However, in some places these traditional agricultural landscapes have been preserved up to date. On the other hand, patches with continuous grassland are very rare and are often preserved only in protected areas. The highest potential for restoration can be seen for permanent grassland and water areas.
\end{abstract}

Keywords: landscape structure, land use, old topographic map, cadastral map, Kyjovská pahorkatina hilly land

\section{Úvod}

Historické struktury krajiny jsou velmi významným fenoménem kulturní krajiny, je v nich zaznamenán historický způsob využívání krajiny a zároveň dodávají území specifický krajinný ráz (Muchová, Petrovič, 2014). V zemědělských typech krajin je z hlediska zachování biodiverzity (Skokanová et al., 2016) a udržitelného hospodaření se zemědělskou půdou (Stejskalová et al., 2012; Dumbrovský, Larišová, 2016) nezbytné zachování či obnova cenných struktur krajiny s tradičním způsobem hospodaření (Hreško et al., 2015; Petrovič et al., 2017; Dawson et al., 2017). Z hlediska krajinné rázu jsou velmi aktraktivní stopy tradičních a regionálně podmíněných způsobů hospodaření - struktura orné půdy, louky, ovocné sady, pastviny, zahrady, chmelnice, vinice, meze (Amici et al., 2017; Špulerová et al., 2015; Súl’ovský et al., 2017). Mapování historických krajinných struktur v Evropě je možné s využitím starých topografických map, 
které jsou pro práce v GIS použitelné z období poloviny 19. století (Skokanová et al., 2012; Fuchs et al., 2015), s využitím podrobných katastrálních map (Hanušin, Štefunková, 2015), případně za použití leteckých snímků, které jsou k dispozici ve stř̌ední Evropě od 30. let 20. století (Mojses, Petrovič, 2013; Šebo, Kopecká, 2014; Skokanová et al., 2016).

Článek je zaměřen na hodnocení změn ve využití krajiny a identifikaci cenných krajinných struktur v typické pahorkatině ve střední Evropě se stopami tradičních a regionálně podmíněných způsobů hospodaření, posouzení jejich významu z hlediska ochrany zemědělského půdního fondu, ochrany př́rody, poskytování ekosystémových služeb. Klíčovým tématem tohoto článku je také potenciál budoucího využití těchto území, možnosti udržení tradičního způsobu hospodaření, prŕpadně možnosti obnovy zaniklých krajinných struktur.

Cílem př́ispěvku je najít odpovědi na tyto výzkumné otázky:

Jaké jsou zásadní změny ve využití makrostruktury krajiny $\mathrm{v}$ Kyjovské pahorkatině, jak jsou prostorově charakterizovány?

Jaké jsou dochované cenné historické krajinné struktury v Kyjovské pahorkatině z hlediska kategorií využití krajiny, jak jsou v současnosti obhospodařovány?

Jaká je kontinuita výskytu dochovaných historických krajinných struktur v tomto území, v jakých obdobích zanikly nedochované struktury krajiny?

Jak jsou chráněny historické dochované krajinné struktury Kyjovské pahorkatiny z hlediska ochrany př́rody a krajiny nebo ochrany kulturního dědictví?

Jaké jsou možnosti obnovy historických krajinných struktur v Kyjovské pahorkatině?

\section{Teoreticko-metodická východiska}

Pro sledování historického vývoje struktury krajiny větších územních celků jsou vhodné staré topografické mapy (Havlíček, Chrudina, 2013). Autoři ve zkoumaném území využili mapy z následujících mapování našeho území: 2. rakouské vojenské mapování 1:28 800 (1836-1841), 3. rakouské vojenské mapování $1: 25000$ (1876), Československé topografické mapy $1: 25000$ (19531955), Československé topografické mapy 1:25000 (1991), Základní mapy České republiky 1:10000 (2002-2006) a ortofotosnímky z roku 2016. V hodnocení zásadních historických změn vývoje struktury krajiny Kyjovské pahorkatiny bylo využití krajiny členěno na devět základních kategorií: orná půda, trvalý travní porost, zahrada a sad, vinice, les, vodní plocha, zastavěná plocha, rekreační plocha, ostatní plocha (Mackovčin, 2009; Skokanová et al., 2012). Při tvorbě map využití krajiny je postupováno jednotnou metodikou platnou pro celé území České republiky, přičemž nejmenší mapovací jednotka má velikost 0,8 ha a minimální šířka jednotlivých polygonů činí $40 \mathrm{~m}$. Detailnější struktura krajiny byla sledována s využitím sady archivních leteckých snímků od roku 1953 do současnosti, za pomoci terénního průzkumu a dostupných fotografíi konkrétních 
zájmových lokalit, vytipovaných na základě hodnocení makrostruktury krajiny z map využití krajiny středního měřítka.

Mapy využití krajiny byly vytvořeny $\mathrm{v}$ softwaru ArcGIS digitalizací z obrazovky nad topografickými mapami georeferencovanými v souřadnicovém systému S-JTSK. Jednotlivé analýzy byly zpracovány v softwaru ArcGIS a jeho extenzích Spatial Analyst, 3D Analyst. V prostředí GIS byly provedeny základní analýzy historického vývoje podílů kategorií využití krajiny, stabilně využívaných ploch, vazba na nadmořské výšky a sklony svahů u trvalých travních porostů, hodnocení detailní struktury krajiny s využitím map Stabilního katastru a leteckých snímků. Pro tvorbu 3D modelu území a odvozených map kategorií nadmořských výšek, sklonů svahů a orientace svahů bylo využito zdrojových dat o nadmořských výškách z databáze ZABAGED ČÚZK. Jako základní jednotka pro analýzy prostorových dat na úrovní geomorfologického celku byla zvolena velikost pixelu $5 \mathrm{~m}$. Prostorová data o ochraně př́rody byla získána z mapových aplikací Agentury ochrany př́rody a krajiny ČR a dostupných mapových serverů regionálních pracovišt' ochrany prŕrody a krajiny.

\section{Modelové území}

Kyjovská pahorkatina patří mezi typické zemědělské oblasti jižní Moravy s vysokým podílem ploch orné půdy ve velkých půdních blocích, s rozsáhlými areály velkoplošných vinic a sadů a naopak nízkými podíly ploch lesů, trvale travních porostů a vodních ploch. Kyjovská pahorkatina má celkovou rozlohu 487 $\mathrm{km}^{2}$. Tento geomorfologický celek se nachází na jižní Moravě a zasahuje do čtyř okresů (Hodonín, Uherské Hradiště, Břeclav a Zlín). Jde o členitou pahorkatinu se střední výškou $235 \mathrm{~m}$ a středním sklonem $3^{\circ} 30^{\prime}$, s úvalovitými a neckovitými údolími a výraznou Čejčskou kotlinou (Demek, Mackovčin, a kol., 2006). Nejvyšší bod Kyjovské pahorkatiny Babí lom má výšku 417,2 m n m. Nejnižší bod se nachází v nadmořské výšce $169,5 \mathrm{~m} \mathrm{n}$. $\mathrm{m}$. V kategorii nadmořských výšek od $169,5 \mathrm{~m}$ do $200 \mathrm{~m}$ se nachází 15,1 \% území, v kategorii od $200 \mathrm{~m}$ do $225 \mathrm{~m} \mathrm{31,1 \%}$

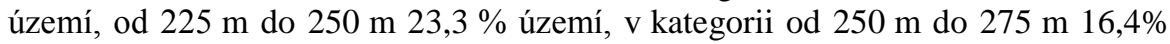
území, u ostatních kategorií nadmořských výšek se pohyboval podíl na území v rozmezí od 2 do $6 \%$. O členitosti Kyjovské pahorkatiny svědčí i zastoupení jednotlivých kategorií svahů: nejvíce jsou zastoupeny střední svahy o sklonu $5^{\circ}$ až $10^{\circ}(31,7 \%$ území) s optimálním využitím v podobě vinic, sadů, lesů či pastvin; dále mírné svahy o sklonu $2^{\circ}$ až $5^{\circ}(32,5 \%)$ s optimálním využitím orná půda, zastavěné plochy, sady, rekreační plochy; plochá území v nivách řek a potoků, roviny, rovinné části teras o sklonu $0^{\circ}$ až $2^{\circ}(29.3 \%)$ s optimálním využitím orná půda, lužní lesy, podmáčené louky, vodní plochy, sady a vinice na terasách. Větší svahy o sklonu $10^{\circ}$ až $15^{\circ}$ zabírají pouze $5,5 \%$ území a jejich optimálním vyžitím je les. Podle orientace svahů jsou v Kyjovské pahorkatině nejvíce zastoupeny svahy s jižní složkou, konkrétně JV, J, JZ (vždy okolo 15 \% území), naopak nejmenší 
zastoupení mají svahy orientované na sever (8\%) a severozápad (9\%), proto je také tato pahorkatina dlouhodobě využívána pro pěstování révy vinné a ovoce.

Obr. 1: Kyjovská pahorkatina

Figure 1: Kyjovská pahorkatina hilly land

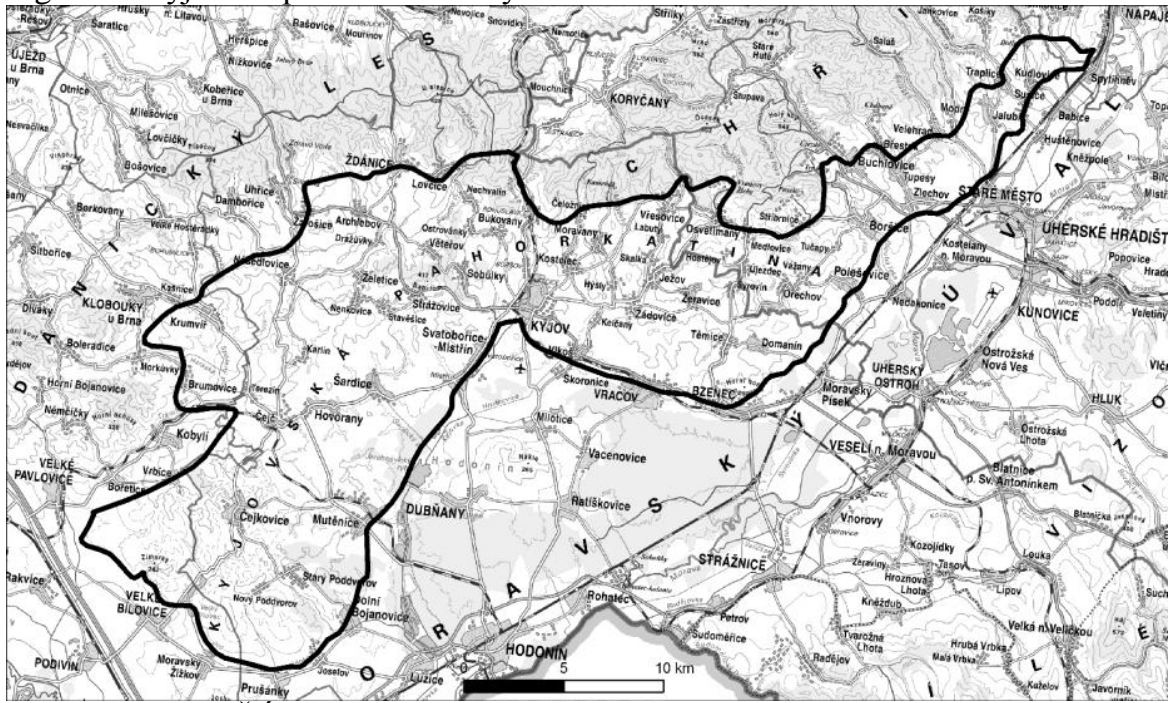

Zdroj: ZM 200, ČÚZK

V Kyjovské pahorkatině se nachází celkem 15 maloplošně zvláště chráněných území, z toho 1 národní přírodní památka, 2 prrírodní rezervace a 12 prrírodních památek. Častým důvodem vyhlášení těchto prrírodně chráněných území byla ochrana jedinečných krajinných struktur nebo dochovaných prvků v krajině. V rámci soustavy chráněných území evropského významu NATURA 2000 je na území Kyjovské pahorkatiny chráněno celkem 13 evropsky významných lokalit a 1 ptačí oblast. Taktéž v několika evropsky významných lokalitách jsou předmětem ochrany cenné historické krajinné struktury; v prŕṕpadě ptačí oblasti Hovransko Čejkovicko je krajinná struktura se stř́idáním maloplošných sadů, vinic a políček spolu se solitérními stromy zásadním biotopem pro ochranu strnada zahradního a strakapouda jižního (Skokanová et al., 2016). Okrajově do území zasahují i prrírodní parky Ždánický les a Chřiby; význam v ochraně př́rody a zachování biodiverzity mají také významné krajinné prvky, kterých je v Kyjovské pahorkatině vymezeno celkem 31 .

V modelovém území Kyjovské pahorkatiny byl již $\mathrm{v}$ jeho dílčích částech hodnocen dlouhodobý vývoj využití krajiny (Havlíček, Chrudina, 2013; Havlíček et al., 2014), komplexně však tento geomorfologický celek z hlediska 
dlouhodobého využití krajiny a historických krajinných struktur dosud nebyl hodnocen.

\section{Změny využití krajiny na základě starých a současných topografických map středního měřítka}

V celém hodnoceném období převládala v Kyjovské pahorkatině orná půda. Její podíl se výrazně zvýšil na konci 19. století a maxima dosahoval v letech 19531954, kdy orná půda tvořila $80 \%$ z celého území (Tab. 1). Nárůst ploch orné půdy v tomto období proběhl na úkor zániku trvalých travních porostů a vodních ploch. V pozdějších obdobích došlo k poklesu podílu ploch orné půdy, zejména díky převodu na velkoplošné vinice, zahrady a sady, zastavěné plochy. V počátečních dvou obdobích (1836-1841 a 1876) byly další plošně největší kategorií využití krajiny Kyjovské pahorkatiny trvalé travní porosty (Tab. 1). Rozsáhlé rozorávání luk a pastvin za účelem zisku orné půdy ke konci 19. století a nepříznivé dopady socialistického způsobu zemědělského hospodaření vedly k poklesu podílu ploch trvalých travních porostů ze $17 \%$ na pouhé $1 \%$ (v roce 1991). V posledních 20 letech sice podíl trvalých travních porostů v Kyjovské pahorkatině mírně narůstá, přesto je stále velmi nízký oproti hodnotám z počátečního období. Z dlouhodobého hlediska je v tomto regionu taktéž významný podíl ploch vinic, který se aktuálně pohybuje okolo $10 \%$ (Tab. 1).

Tab. 1: Vývoj využití krajiny v Kyjovské pahorkatině od roku 1836 do roku 2015 (podíl $\mathrm{v} \%$ )

Table 1: Development of land use classes extent (in \%) in the Kyjovská pahorkatina hilly land between 1836 and 2015

\begin{tabular}{|c|c|c|c|c|c|c|}
\hline $\begin{array}{c}\text { Kategorie } \\
\text { využití }\end{array}$ & $\begin{array}{l}1836- \\
1841 \\
\end{array}$ & 1876 & $\begin{array}{l}1953- \\
1954 \\
\end{array}$ & 1991 & $\begin{array}{l}2002- \\
2006 \\
\end{array}$ & $\begin{array}{l}2014- \\
2015 \\
\end{array}$ \\
\hline orná půda & 66,5 & 77,3 & 79,6 & 68,3 & 68,3 & 66,0 \\
\hline $\begin{array}{l}\text { trvalý travní } \\
\text { porost }\end{array}$ & 16,7 & 8,3 & 2,9 & 1,4 & 2,5 & 3,1 \\
\hline zahrada a sad & 0,2 & 0,1 & 1,7 & 4,1 & 4,2 & 3,4 \\
\hline vinice & 6,6 & 5,4 & 4,6 & 10,4 & 8,5 & 9,7 \\
\hline les & 6,2 & 5,7 & 6,2 & 7,2 & 7,6 & 7,9 \\
\hline vodní plocha & 1,0 & 0,0 & 0,0 & 0,2 & 0,2 & 0,3 \\
\hline $\begin{array}{l}\text { zastavěná } \\
\text { plocha }\end{array}$ & 2,8 & 3,1 & 5,0 & 8,1 & 8,5 & 9,3 \\
\hline $\begin{array}{l}\text { rekreační } \\
\text { plocha }\end{array}$ & 0,0 & 0,0 & 0,0 & 0,2 & 0,2 & 0,3 \\
\hline ostatní plocha & 0,0 & 0,0 & 0,0 & 0,1 & 0,1 & 0,1 \\
\hline Celkem & 100,0 & 100,0 & 100,0 & 100,0 & 100,0 & 100,0 \\
\hline
\end{tabular}


Zatímco do roku 1953-1954 se vyskytovaly vinice spolu s ovocnými sady a drobnými políčky v mozaikovité ekologicky atraktivní zemědělské krajině, dnes jsou převážně tvořeny velkoplošnými areály zakládanými hromadně zemědělskými podniky v druhé polovině 20. století. Kyjovská pahorkatina má také vhodné podmínky pro pěstování ovoce. Podíl ploch zahrad a sadů se zvýšil zejména díky zakládání velkoplošných sadů v druhé polovině 20. století. Od poloviny 19. století do poloviny 20 . století byly ovocné stromy pěstovány běžně i na polích a ve vinicích, takže jejich zastoupení není na topografických mapách vždy zřetelné, př́padně je zahrnuto $\mathrm{v}$ mapových legendách $\mathrm{v}$ kategoriích pole $\mathrm{s}$ ovocnými stromy, nebo vinice s ovocnými stromy. Lesy jsou $\mathrm{v}$ Kyjovské pahorkatině zastoupeny pouze sporadicky, jejich podíl nepřekonal hranici $8 \%$ (tab. 1). Jsou lokalizovány převážně ve vyšších nadmořských výškách v okolí nejvyšší kóty Babí lom u Strážovic, v okolí Starého Poddvorova a Čejkovic a v části Kyjovské pahorkatiny navazující na Chřiby (u Osvětiman, Buchlovic). Z nížinných lesů se v modelovém území nachází pouze doubrava vokolí řeky Kyjovky severně od Mutěnic. Zastavěné plochy během sledovaného období zaznamenaly trojnásobný nárůst, aktuálně je jejich podíl $9 \%$ a jsou tedy třetí plošně nejrozsáhlejší kategorií využití krajiny v území. Kromě Kyjova (11,5 tis. obyvatel) nejsou zastoupena v Kyjovské pahorkatině žádná větší města. Naopak je zde vysoký podíl menších měst a velkých obcí s počtem obyvatel od 2000 do 5000 (Vracov, Bzenec, Mutěnice, Svatobořice-Mistřín, Ždánice, Čejkovice, Šardice, Dolní Bojanovice, Buchlovice, Boršice, Polešovice). Podíl zastavěných ploch v tomto regionu byl vázán především na růst rezidenčních ploch a ploch zemědělských areálů a objektů, které byly budovány od poloviny 20 . století na okrajích intravilánu obcí a měst, případně jako samostatné areály ve volné krajině. Ve městech a některých větších obcích byl růst zastavěných ploch vázán i na vznik průmyslových a administrativních ploch. Specifickým vývojem si v Kyjovské pahorkatině prošly vodní plochy, jejichž podíl se výrazně snížil již v počátečním období mezi roky 1836-1841 a 1876, kdy zanikly nejen dvě největší přírodní jezera v regionu (Kobylské a Čejčské jezero), ale i rybniční soustavy na Kyjovce, Trkmance a dalších vodních tocích. Obnova rybníků v původním rozsahu se dosud neuskutečnila. Sporadicky vznikají spíše menší vodní plochy, s výjimkou vodní nádrže Velký Bílovec na Prušánce.

Významné změny využití krajiny u trvalých travních porostů v Kyjovské pahorkatině vedly autorský kolektiv $\mathrm{k}$ doplňujícím analýzám, konkrétně ve vztahu $\mathrm{k}$ charakteristikám reliéfu. Zatímco $\mathrm{v}$ počátečních třech obdobích byly trvalé travní porosty nejvíce zastoupeny v nejnižší nadmořské výšce do 199,9 m, v posledních letech je to již v druhé kategorii nadmořských výšek $(200,0-224,9$ $\mathrm{m})$. Lze tedy usuzovat na silný trend zániku luk a pastvin v nivách vodních toků, což je podpořeno i nejvýraznějším poklesem podílu v nejnižších nadmořských výškách - z 5 \% v roce 1836-1841 na téměř žádné v roce 1991. Nejmenší úbytek podílu trvalých travních porostů byl zaznamenán ve středních a vyšších nadmořských výškách (od 275 do 325 m). V těchto nadmořských výškách se 
nacházejí často významné zachovalé stepní lokality na poměrně členitých svazích.

Vztah dlouhodobého vývoje podílu trvalých travních porostů ke sklonu svahů v Kyjovské pahorkatině skutečně potvrzuje nejvyšší pokles podílu v nivách vodních toků, prrípadně na jejich terasách, které mají ploché dno (skon svahů od 0,0 do $\left.1,9^{\circ}\right)$. V krajině Kyjovské pahorkatiny tak zanikly rozsáhlé plochy nivních zamokřených luk, které byly nahrazeny ornou půdou, př́padně se později staly součástí rozrůstajících se sídel. Taktéž u mírnějších svahů se sklonem $2,0-4,9^{\circ}$ byl propad podílu trvalých travních porostů velmi významný. Méně významný pokles podílu byl zaznamenán u svahů se sklonem $5,0-9,9^{\circ}$ a $10,0-19,9^{\circ}$. Na některých př́krých svazích je dochována původní stepní vegetace, která je v této krajině velmi cenná a často i zákonem chráněna.

Tab. 2: Podíl stabilně využívaných ploch v Kyjovské pahorkatině v období 18362015

Table 2: Proportion of non-changed land use classes in the Kyjovská pahorkatina hilly land in 1836-2016

\begin{tabular}{|l|r|r|}
\hline \multicolumn{1}{|c|}{ Stabilní plochy } & Výměra v ha & \multicolumn{1}{c|}{ Procento } \\
\hline orná půda & 22863,50 & 46,9 \\
\hline trvalý travní porost & 93,71 & 0,2 \\
\hline zahrada a sad & 0,00 & 0,0 \\
\hline vinice & 493,41 & 1,0 \\
\hline les & 2299,81 & 4,7 \\
\hline vodní plocha & 0,00 & 0,0 \\
\hline zastavěná plocha & 1281,83 & 2,6 \\
\hline rekreační plocha & 0,00 & 0,0 \\
\hline ostatní plocha & 0,00 & 0,0 \\
\hline Celkem & 27032,26 & 55,5 \\
\hline
\end{tabular}

V Kyjovské pahorkatině byla na základě studia topografických map z let 1836-2015 stabilně využívána více než polovina ploch (tab. 2). Nejvyšší podíl vykazovala orná půda, ostatní kategorie využití krajiny byly zastoupeny velmi malými podíly. Potvrzuje se tak, že stabilně využívané trvalé travní porosty jsou $\mathrm{v}$ tomto regionu velmi vzácné. Jak již bylo zmíněno, většina $\mathrm{z}$ nich je chráněna $\mathrm{v}$ rámci maloplošných zvláště chráněných území. Velmi nízký podíl vykazovaly $\mathrm{i}$ vinice, u kterých došlo často k zániku menších ploch a nahrazení velkoplošnými 
vinicemi. Vodní plochy nebyly v Kyjovské pahorkatině kontinuálně dochovány ani $\mathrm{v}$ jednom př́padě; $\mathrm{k}$ jejich částečné obnově dochází až v pozdějších obdobích. Zahrady a sady taktéž nevykazují žádné stabilně využívané plochy, nicméně je zde zapotřebí zmínit, že topografické mapy nepostihují v měřítku map a použitou legendou smíšené plochy vinic či polí se stromy, které tvoří v tomto území tzv. mozaikovitou/tradiční strukturu krajiny.

\section{Historické krajinné struktury s využitím podrobných map a leteckých snímků}

Identifikace cenných historických krajinných struktur v Kyjovské pahorkatině probíhala s využitím leteckých snímků z poloviny 20. století, leteckých snímků ze současnosti (2017) a detailních map stabilního katastru v měřítku 1:2880 z první poloviny 19. století. Mezi cenné historické struktury krajiny, které mají zásadní význam pro ekologické funkce, biodiverzitu území i vnímání krajinného rázu patří v Kyjovské pahorkatině především mozaikovitá struktura maloplošných polí, sadů a vinic, která se vyskytovala v polovině 19 . století u většiny obcí Kyjovské pahorkatiny. Takto dochované plochy historických krajinných struktur jsou cenné nejen pro ekologické funkce, ale i jako atraktivní lokality z hlediska cestovního ruchu, který je vázán v Kyjovské pahorkatině především na vinařství. Zkoumáním všech dochovaných krajinných struktur byly zjištěny některé obecné trendy. Na území katastrů obcí se nacházelo několik oblastí s mozaikovitou strukturou krajiny, která však byla výrazně narušena $\mathrm{v}$ druhé polovině 20 . století při kolektivizaci zemědělství. Při tomto procesu docházelo ke scelování pozemků, rušení drobných remízků, polních cest, terasování svahů. $\mathrm{Na}$ př́kladu několika obcí z Kyjovské pahorkatiny lze dokumentovat nejčastější důvody zániku mozaikovité struktury krajiny a důvody pro jejich zachování.

Pro obce v Kyjovské pahorkatině bylo typické využití mozaikovitých struktur krajiny ve svažitém reliéfu v těsném zázemí sídla, př́ípadně v širším okolí $\mathrm{v}$ drobné zemědělské držbě mimo pozemků panských dvorů a statků. $\mathrm{V}$ př́padě větších komplexů drobné držby nebylo možné $\mathrm{v}$ rámci kolektivizace zemědělství v 2. polovině 20. století udržet všechny plochy mozaikovité struktury krajiny, přičemž častěji byly na základě požadavků místních hospodářů zachovány v bezprostředním okolí sídel, př́ípadně v okolí lokalit vinných sklepů. Naopak většímu tlaku na likvidaci podléhaly lokality vzdálenější od sídel - viz např. zaniklá mozaikovitá struktura krajiny na okraji katastru Bzence, převedená na velkoplošné vinice (obr. 2 a 3). Obdobně zanikla cenná mozaikovitá struktura krajiny i v dalších lokalitách Kyjovské pahorkatiny (Čejkovice, Vrbice, Šardice, Archlebov). 
Obr. 2: Krajina v okolí města Bzenec s mozaikovitou strukturou krajiny drobných vinic, polí a sadů na mapě Stabilního katastru z roku 1827

Figure 2: Landscape around town of Bzenec with a traditional mosaic of small vineyards, orchards and arable fields, captured at the map of Stable cadastre from 1827

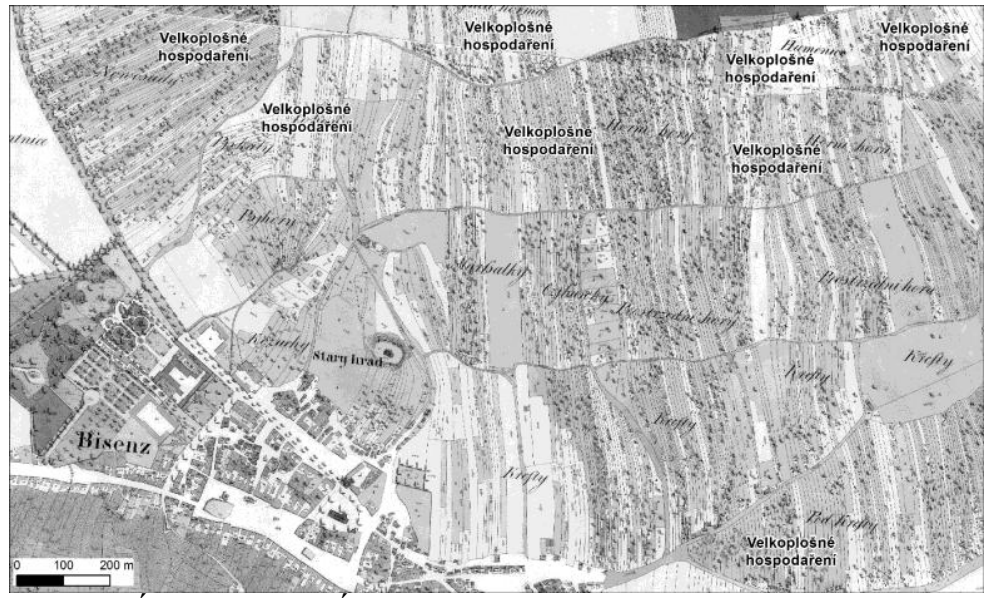

Zdroj: VÚKOZ, v.v.i., ÚAZK

Obr. 3: Bzenec a okolí s mozaikovitou strukturou krajiny drobných vinic, polí, sadů a velkoplošným způsobem hospodaření na leteckém snímku z roku 2016

Figure 3: Town of Bzenec and surroundings with a mosaic of small vineyards, orchards and arable fields and with large scale landscape management, captured at the aerial photo from 2016

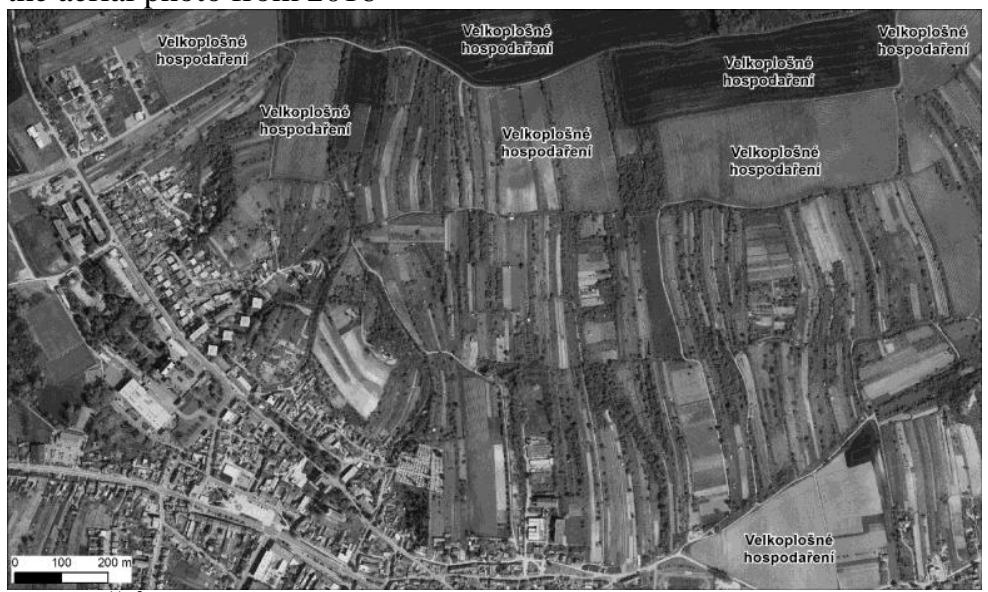

Zdroj: ČUZK 


\section{Diskuze}

Za dochované cenné historické krajinné struktury v Kyjovské pahorkatině z hlediska kategorií využití krajiny lze považovat především mozaiky drobných polí, sadů a vinic, které udávají krajině typický ráz a jedinečnost, což je v souladu se studiemi krajiny z jiných zemí (Amici et al., 2017; Špulerová et al., 2015). Bohužel v současnosti nejsou dostatečně chráněny $z$ hlediska ochrany př́rody a krajiny, ani z hlediska kulturně historických hodnot. Jednou z možností ochrany těchto prvků krajiny v České republice je zahrnutí území mezi krajinné památkové zóny (Kuča et al., 2015). Původní způsob hospodaření na drobných pozemcích se s postupnou mechanizací u drobných a středních vinařů mění, často jsou jednotlivé pozemky skupovány a zcelovány a z krajiny Kyjovské pahorkatiny tak mizí solitérní ovocné stromy (Skokanová et al., 2016). Z rozhovorů s místními odborníky z oblasti krajinného a územního plánování a odborníky na cestovní ruch vyplývá, že jedinečnost mozaikovité struktury krajiny je jednou z hlavních atraktivit regionu pro rozvoj cestovního ruchu. Význam historických struktur krajin pro cestovní ruch a atraktivitu území zdůrazňují i další studie ze střední Evropy (Mojses, Petrovič, 2013; Kuča, 2014; Kučera et al., 2015; Súl'ovský et al., 2017). Za další velmi cenné historické struktury krajiny Kyjovské pahorkatiny je možné považovat trvalé travní porosty, které se kontinuálně dochovaly pouze na několika lokalitách a většinou jsou chráněny z hlediska ochrany přírody a krajiny. Obdobný významný pokles podílu ploch trvalých travních porostů byl v okolí zaznamenán pouze u Dyjsko-svrateckého úvalu (Demek, Havlíček, Mackovčin, 2009). Kontinuita u vodních ploch $\mathrm{v}$ tomto území nebyla zachována, proto je vhodná podpora obnovy vodních ploch a mokřadů v regionu (Havlíček at al., 2014). $\mathrm{V}$ prrípadě vodních ploch docházelo $\mathrm{k}$ významnému úbytku ploch již na konci 19. století v souvislosti s rozmachem pěstování technických zemědělských plodin (Skokanová, Falt’an, Havlíček, 2016), růstem počtu obyvatelstva a specificky v regionu i s rozvojem cukrovarnictví (Havlíček et al., 2014, Pavelková et al., 2016). Cenné historické mozaikovité struktury drobných polí, vinic a sadů byly systematicky likvidovány až v druhé polovině 20 . století a kvưli častým rozsáhlým terénním úpravám spojenými s terasováním svahů již nejsou obnovitelné v původní podobě. Mezi zásadní hybné síly vedoucí $\mathrm{k}$ zániku trvalých travních porostů v Kyjovské pahorkatině patří: agrární revoluce v 19. století orientovaná na produkci obilovin a technických plodin s vysokými nároky na plochy orné půdy (Skokanová, Falt’an, Havlíček, 2016), opouštění typického chovu ovcí kvůli nižšímu odbytu a konkurenci jiných druhů oděvních látek v 19. století, rozvoj cukrovarnictví $\mathrm{v}$ obcích a městech $\mathrm{v}$ Kyjovské pahorkatině a $\mathrm{v}$ okolí $\mathrm{v}$ druhé polovině 19. století (Havlíček, Dostál, Svoboda, 2013), socialistický způsob hospodaření $\mathrm{v}$ druhé polovině 20. století s typickými projevy rozorávání luk a mezí, scelování pozemků, rušení polních cest a přilehlých trvalých travních porostů, terasování členitých svahů s pastvinami a loukami. Údržba stávajících 
lokalit trvalých travních porostů a obnova původních ploch trvalých travních porostů v Kyjovské pahorkatině je žádoucí z několika důvodů: a) zachování a zvýšení biodiverzity vzácných rostlinných a živočišných druhů vázaných na velmi cenné xerotermní stepní lokality a zamokřené louky v nivách řek a potoků, b) zlepšení ochrany zemědělského půdního fondu před vodní a větrnou erozí, c) zlepšení ekologických funkcí krajiny, d) zlepšení krajinného rázu zemědělské krajiny. Možnosti obnovy cenných historických krajinných struktur lze využít při komplexních pozemkových úpravách, v územním plánu obcí, při plánování ÚSES, zlepšení prostupnosti krajiny, ochrany zemědělského půdního fondu a zlepšení retenční schopnosti krajiny. Velký potenciál má v tomto regionu zejména obnova zelené infastruktury krajiny, obnova mokřadů a vodních ploch. První výstup výzkumných aktivit $\mathrm{z}$ vývoje využití krajiny a historických krajinných struktur v Kyjovské pahorkatině je založen převážně na hodnocení vývoje využití krajiny z map středního měřítka, detailnější mapy Stabilního katastru byly georeferencovány a použity pro srovnání a ukázky dochovaných a zaniklých krajinných struktur. V rámci dalších výzkumných aktivit VÚKOZ, v.v.i. probíhá vektorizace detailní struktury krajiny z těchto map a aktuálních leteckých snímků, které budou prezentovány v navazujících publikacích.

\section{Závěr}

Z hlediska historické struktury krajiny je zánik trvalých travních porostů podél vodních toků, zánik drobných i rozsáhlejších pastvin či mozaikovitého způsobu zemědělského hospodaření v krajině nejzásadnější změnou v krajině Kyjovské pahorkatiny. Pro toto území je v zemědělské krajině typické zastoupení vysokého podílu velkých bloků orné půdy běžně o velikosti větší než 100 ha. Paradoxně ani aktuální způsob podnikání ve vinařství nenahrává udržování a zakládání drobných vinic a podpoře původní mozaikovité krajiny. Obnovovány a nově zakládány jsou především středně velké vinice přizpůsobené mechanizaci a optimalizaci nákladů místních vinařů.

Trvalé travní porosty jsou velmi cenným prvkem v krajinné struktuře $\mathrm{v}$ Kyjovské pahorkatině. Stabilně využívané plochy trvalých travních porostů jsou v této krajině velmi vzácné a jsou často zahrnuty do chráněných území. Dvě třetiny maloplošně zvláště chráněných území v Kyjovské pahorkatině jsou vyhlášeny kvưli ochraně stepní vegetace. U dalších maloplošně zvláště chráněných území jsou trvalé travní porosty taktéž zastoupeny (např. u bývalých těžebních areálů cihelen a pískoven). Trvalé travní porosty mají významné zastoupení také u evropsky významných lokalit, ptačích oblastí, či významných krajinných prvků v tomto území.

Vodní plochy na území Kyjovské pahorkatiny na konci 19. století byly vysušeny a převedeny převážně na ornou půdu, případně louky. Od druhé poloviny dochází postupně k obnově či budování nových vodních ploch, přesto je zde ještě velký potenciál k obnově vodních ploch či mokřadů v původních lokalitách. 


\section{Poděkování}

Článek je součástí projektu QJ1630422 - Ochrana půdy formou optimalizace prostorových a funkčnich parametrů prvkü krajinné struktury v pozemkových úpravách, který byl podpořen programem KUS Národni zemědělskou agenturou pro vědu a výzkum.

\section{Literatura}

AMICI, V. - MACCHERINI, S. - SANTI, E. - TORRI, D. - VERGARI, F. V DEL MONTE, M. 2017. Long-term patterns of change in a vanishing cultural landscape: A GIS-based assessment. In Ecological Informatics. vol. 37, pp. 3851.

DAWSON, L. - ELBAKIDZE, M. - ANGELSTAM, P. - GORDON, J. 2017. Governance and management dynamics of landscape restoration at multiple scales: Learning from successful environmental managers in Sweden. In Journal of Environmental Management. vol. 197, pp. 24-40.

DEMEK, J. - MACKOVČIN, P. (eds.) et al. 2006. Hory a nižiny: Zeměpisný lexikon $\check{C} R$. Vydání II. Brno: AOPK ČR, 2006. $582 \mathrm{~s}$.

DUMBROVSKÝ, M. - LARIŠOVÁ, L. 2016. The influence of different technologies of soil processing on infiltration properties of soil in the cambisols area of the opava district. In Acta Universitatis Agriculturae et Silviculturae Mendelianae Brunensis. vol. 64, no. 5, pp. 1495-1505.

FUCHS, R. - VERBURG, P. H. - CLEVERS, J. G. P. W. - HEROLD, M. 2015. The potential of old maps and encyclopaedias for reconstructing historic European land cover/use change. In Applied Geography. vol. 59, pp. 43-55.

HAVLÍĆEK, M. - SVOBODA, J. - DOSTÁL, I. 2013. Vliv rozvoje cukrovarnictví v okrese Hodonín na změny využití krajiny a dopravní infrastrukturu. In Listy cukrovarnické a řepařské. roč. 129, č. 9-10, s. 312-316.

HAVLÍČEK, M. - PAVELKOVÁ, R. - FRAJER, J. - SKOKANOVÁ, H. 2014. The long-term development of water bodies in the context of land use: The case of the Kyjovka and Trkmanka River Basins (Czech Republic). In Moravian Geographical Reports. vol. 22, no. 4, pp. 39-50.

HREŠKO, J. - PETROVIČ, F. - MIŠOVIČOVÁ, R. 2015. Mountain landscape archetypes of the Western Carpathians (Slovakia). In Biodiversity and Conservation. vol. 24, no. 13, pp. 3269-3283.

KUČA, K. (ed.) - KUČOVÁ, V. - SALAŠOVÁ, A. - VOREL, I. - WEBER, M. a kol. 2015. Krajinné památkové zóny České republiky. Praha: Národní památkový ústav, 2015. $511 \mathrm{~s}$.

KUČA, K. 2014. Oblasti dochovaných strukturálně výrazných plužin v České republice. In Zprávy památkové péče, 74, č. 1, s. 34-39. 
KUČERA, P. - NOVÁK, J. - LÖW, J. - DOHNAL, T. 2015. Historical landscape structures and their importance for landscape character. In Acta Universitatis Agriculturae et Silviculturae Mendelianae Brunensis. vol. 63, no. 1, pp. 49-57.

MACKOVČIN, P. 2009. Land use categorization based on topographic maps. In Acta Pruhoniciana. vol. 91, pp. 5-13.

MOJSES, M. - PETROVIČ, F. 2013. Land use changes of historical structures in the agricultural landscape at the local level - Hriňová case study. In Ekologia. vol. 32, pp. 1-12.

MUCHOVÁ, Z. - PETROVIČ, F. 2014. Impact of land consolidation on the visual characteristics (scenery) of a landscape. In Journal of Central European Agriculture. vol. 15, no 1, pp. 76-85.

PAVELKOVÁ, R. - FRAJER, J. - HAVLÍČEK, M. - NETOPIL, P. ROZKOŠNÝ, M. - DAVID, V. - DZURÁKOVÁ, M. - ŠARAPATKA, B. 2016. Historical ponds of the Czech Republic: an example of the interpretation of historic maps. In Journal of Maps. vol. 12, supplement 1, pp. 551-559.

PETROVIČ, F. - STRÁNOVSKÝ, P. - MUCHOVÁ, Z. - FALŤAN, V. SKOKANOVÁ, H. - HAVLÍČEK, M. - GÁBOR, M. - ŠPULEROVÁ, J. 2017. Landscape-ecological optimization of hydric potential in foothills region with dispersed settlements - a case study of Nová Bošáca, Slovakia. In Applied Ecology and Environmental Research. vol. 15, no. 1, pp. 379-400.

SKOKANOVÁ, H. - HAVLÍČEK, M. - BOROVEC, R. - DEMEK, J. EREMIÁŠOVÁ, R. - CHRUDINA, Z. - MACKOVČIN, P. - RYSKOVÁ, R. - SLAVÍK, P. - STRÁNSKÁ, T. - SVOBODA, J. 2012. Development of land use and main land use change processes in the period 1836-2006: Case study in the Czech Republic. In Journal of Maps. vol. 8, no. 1, pp. 88-96.

SKOKANOVÁ, H. - FALŤAN, V. - HAVLÍČEK, M. 2016. Driving forces of main landscape change processes from past 200 years in Central Europe differences between old democratic and post-socialist countries. In Ekológia (Bratislava).vol. 35, no. 1, pp. 50-65

SKOKANOVÁ H. - HAVLÍĆEK M. - UNAR P. - JANÍK D. - ŠIMEČEK K. 2016. Changes of Ortolan Bunting (Emberiza hortulana L.) habitats and implications for the species presence in SE Moravia, Czech Republic. In Polish Journal of Ecology. vol. 64, no. 1, pp. 98-112.

STEJSKALOVÁ, D. - KARÁSEK, P. - PODHRÁZSKÁ, J. - TLAPÁKOVÁ, L. 2012. Methods of determining landscape functions and their evaluation: A case study of Hustopeče, Czech Republic. In Moravian Geographical Reports. vol. 20, no. 2, pp. 17-24.

SÚLOVSKÝ, M. - FALŤAN, V. - SKOKANOVÁ, H. - HAVLÍČEK M. PETROVIČ, F. 2017. Spatial analysis of long-term land-use development in regard to physiotopes: case studies from the Carpathians. In Physical geography. vol. 38 , no. 5 , pp. $470-488$. 
ŠEBO, D. - KOPECKÁ, M. Abandonment of agricultural landscape after 1989: A case study from the Považie Region, Slovakia. In Geografický časopis. vol. 66, no. 4, pp. 323-339.

ŠPULEROVÁ, J. - PISCOVÁ, V. - GERHÁTOVÁ, K. - BAČA, A. KALIVODA, H. - KANKA, R. 2015. Orchards as traces of traditional agricultural landscape in Slovakia. In Agriculture, Ecosystems and Environment. vol. 199, pp. 67-76.

\section{DEVELOPMENT OF LAND USE OF THE KYJOVSKÁ PAHORKATINA HILLY LAND, DISCUSSION OF VALUABLE HISTORICAL LANDSCAPE STRUCTURES, THEIR PROTECTION, MANAGEMENT AND POTENTIAL FOR RESTORATION}

\section{Summary}

Historical landscape structures represent significant feature of a cultural landscape. They both records historical landscape management and, at the same time, give the landscape a specific landscape character. Mapping historical landscape structures in Europe can be done with the help of old topographic maps, which can be used for GIS work from the mid 19-th century, with the help of detailed cadastral maps, or with the help of aerial photographs available in Central Europe since the 1930s.

In the region of the Kyjovská pahorkatina hilly land, arable land prevailed throughout the researched period (1837-2015). Its proportion steeply increased at the end of 19th century and peaked in 1953-1953 when the arable land covered nearly $80 \%$ of the whole territory. Increase of the arable land was mainly at the detriment of permanent grassland and water areas. In later periods, the proportion of arable land decreased, namely due to planting large scale vineyards and orchards and spread of built-up areas. Especially during the 19th century, permanent grassland was also quite spread. It was ploughed already at the end of the 19th century and its size further decreased during the socialist period (1948-1989), resulting in tremendous drop from $17 \%$ to $1 \%$. Vineyards represent third land use category that is a prominent feature of the Kyjovská pahorkatina hilly land and its proportion nowadays oscillates around $10 \%$.

The biggest changes in historical landscape structures of the Kyjovská pahorkatina hilly land concerned disappearance of meadows along water courses, small as well as large pastures and a mosaic of small agricultural holdings, representing traditional agricultural landscapes with small vineyards, orchards and arable fields. Nowadays typical features of the agricultural landscape are represented by large blocks of arable fields with size bigger than 100 ha. Even in the viticulture, the trend of planting large vineyards in order to optimize costs doesn't help in the management and preservation of former traditional mosaic 
landscape. Permanent grassland represents another valuable feature of the Kyjovská pahorkatina hilly land. Grassland with long-term continuity is very rare and is often included in small nature protected areas, sites of community importance, bird areas and significant landscape elements. The last feature, quite common in the past, is represented by water areas. They were dried at the end of the 19th century and turned mainly into arable land. Even though there have been efforts to restore or built new water areas since the second half of the 20th century, there is still a big potential for restoration of many water areas or wetlands in their former localities.

Mgr. Marek Havlíček, Ph.D., Mgr. Hana Skokanová, Ph.D.

Výzkumný ústav Silva Taroucy pro krajinu a okrasné zahradnictví, v.v.i.

Lidická 25/27, 60200 Brno, Česká republika

E-mail: marek.havlicek@vukoz, hanka@skokan.net

Prof. Dr. Ing. Bořivoj Šarapatka, CSc., Mgr. Patrik Netopil, Ph.D.

Katedra ekologie a životního prostředí

Př́rodovědecká fakulta

Univerzita Palackého v Olomouci

Šlechtitelů 241/27, 78371 Olomouc, Česká republika

E-mail: borivoj.sarapatka@upol.cz, patrik.netopil@upol.cz

RNDr. Renata Pavelková, Ph.D.

Katedra geografie

Př́rodovědecká fakulta

Univerzita Palackého v Olomouci

tř. 17. listopadu, 77146 Olomouc, Česká republika

E-mail: renata.pavelkova@upol.cz 